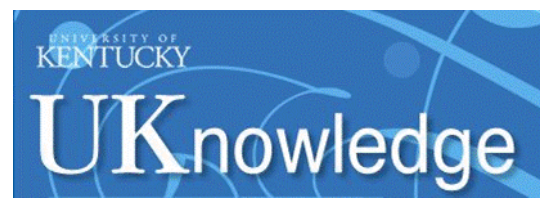

University of Kentucky

UKnowledge

\title{
Making Space for Women: Explaining Citizen Support for Legislative Gender Quotas in Latin America
}

\author{
Tiffany D. Barnes \\ University of Kentucky, tiffanydbarnes@uky.edu \\ Abby Córdova \\ University of Kentucky, abby.cordova@uky.edu
}

Follow this and additional works at: https://uknowledge.uky.edu/polsci_facpub

Part of the Political Science Commons

Right click to open a feedback form in a new tab to let us know how this document benefits you.

\section{Repository Citation}

Barnes, Tiffany D. and Córdova, Abby, "Making Space for Women: Explaining Citizen Support for Legislative Gender Quotas in Latin America" (2016). Political Science Faculty Publications. 9. https://uknowledge.uky.edu/polsci_facpub/9

This Article is brought to you for free and open access by the Political Science at UKnowledge. It has been accepted for inclusion in Political Science Faculty Publications by an authorized administrator of UKnowledge. For more information, please contact UKnowledge@lsv.uky.edu. 


\title{
Making Space for Women: Explaining Citizen Support for Legislative Gender Quotas in Latin America
}

\author{
Digital Object Identifier (DOI) \\ https://doi.org/10.1086/685379 \\ Notes/Citation Information \\ Published in The Journal of Politics, v. 78, no. 3. \\ (c) 2016 by the Southern Political Science Association. All rights reserved.
}

The copyright holder has granted the permission for posting the article here. 


\section{Making Space for Women: Explaining Citizen Support for Legislative Gender Quotas in Latin America}

Tiffany D. Barnes, University of Kentucky

Abby Córdova, University of Kentucky

Gender quotas have been adopted in over a hundred countries in an effort to address gender disparities in national legislatures. Yet the determinants of citizen support for gender quota policies remain largely understudied. We develop a theory that emphasizes the impact of institutional performance and political values to explain citizen support for gender quotas and how these two factors differentially influence men's and women's quota support. Based on data for 24 Latin American countries, we find that citizens in countries with relatively good governance quality who express a strong preference for government involvement to improve citizens' well-being show the highest levels of quota support. Further, whereas good governance increases quota support at a higher rate among men than women, preferences for government involvement exert a stronger influence on women's support for quotas. Consequently, good governance quality reduces the gender gap in quota support by substantially increasing men's support for quotas.

W omen are underrepresented in the vast majority of political decision-making bodies worldwide (Bauer and Tremblay 2011; Escobar-Lemmon and Taylor-Robinson 2005; O'Brien 2015). This global trend undermines one of democracy's core principles - political equality (Dahl 2006). In light of this challenge, since the early 1990s, international organizations have pressed for government action to correct gender inequalities in political representation. These initiatives have resulted in the enactment of gender quota policies in more than a hundred nations (IDEA 2015), with Latin America being "in the vanguard of the gender quota movement" (Jones 2009, 56). As of 2015, close to half the countries in this region had implemented a statemandated legislative gender quota - a law requiring parties to reserve space for women on their list of legislative candidates.

Extant research has examined the effectiveness of quotas for increasing women's numeric representation (O'Brien and Rickne 2016 ; Schwindt-Bayer 2009; Tripp and Kang 2008), their effect on the representation of ordinary women's interests (Barnes 2016; Franceschet and Piscopo 2008), and their impact on symbolic representation (Alexander 2012; Barnes and Burchard 2013; Clayton 2015; Córdova and Rangel, forthcoming; Zetterberg 2009). Scholars have also explored the influence of international advocates (Bush 2011; Hughes, Krook, and Paxton 2015) and domestic elites (Htun and Jones 2002) in the initial adoption of gender quotas. Yet a fundamental question has received little attention: What factors promote higher levels of citizen support for state-mandated legislative gender quotas?

Citizen support for quota policies has important implications for the legitimacy of democratic regimes. If quota adoption is met with low approval, increases in women's numeric representation in parliament may ultimately come at the cost of political legitimacy (Meier 2008). The legitimacy of the political system will always be in question as long as a large share of citizens do not perceive institutions designed to select representatives as "the most appropriate and proper ones" (Lipset 1983, 64). If citizens do not regard political institutions as legitimate, they may disengage from the political system, resulting in low participation and consequently in weak democracy. Indeed Clayton $(2015,26)$ provides evidence that when gender quotas are adopted

Tiffany D. Barnes (tiffanydbarnes@uky.edu) is an assistant professor in political science at the University of Kentucky, 1615 Patterson Office Towers, Lexington KY, 40506. Abby Córdova (abby.cordova@uky.edu) is an assistant professor in political science at the University of Kentucky, 1615 Patterson Office Towers, Lexington KY, 40506.

Data and supporting materials necessary to reproduce the numerical results in the paper are available in the JOP Dataverse (https://dataverse.harvard.edu /dataverse/jop). An online appendix with supplementary material is available at http://dx.doi.org/10.1086/685379.

The Journal of Politics, volume 78, number 3. Published online May 13, 2016. http://dx.doi.org/10.1086/685379 
"without local buy-in," quotas generate "negative unintended attitudinal reactions." Her findings indicate that perceiving quotas as illegitimate ultimately leads citizens to disengage with the polity.

We contribute to the gender and public opinion literatures by developing and systematically testing an integrative theory of how individuals' political values and a country's institutional performance influence citizen support for state-mandated legislative gender quotas. We theorize that, at the individual level, citizens who view the government as responsible for improving ordinary citizens' well-beingand hence support government involvement-will exhibit greater support for quota policies. Individual-level mechanisms are not, however, sufficient to explain variation in support for quotas across countries. We also posit that heuristic information derived from governance quality moderates the relationship between individual preferences for government involvement and support for quotas. More specifically, our theory highlights the importance of a government's track record to consistently deliver positive policy outcomes across issue areas for cultivating quota support.

If the capacity of the entire government apparatus is limited, citizens are likely to be cynical about its ability to deliver promised outcomes and thus will perceive the adoption of quotas as largely inconsequential for advancing equality in society. Consequently, in this case, citizens will exhibit low levels of support for quotas. Moreover, poor governance will attenuate the positive impact of individual preferences for government involvement on support for quotas. In sum, simply favoring government involvement in principle is insufficient to engender support for quotas when in practice one's government has failed to demonstrate that it can make a substantial difference through the implementation of public policies. As we show below, the theory we develop also allows us to explain the cross-national variation that exists between men and women in levels of quota support.

Latin America offers a fitting setting to test our hypotheses. First, the substantial variation in governance quality across Latin American countries allows us to evaluate our theorized connection between institutional performance and quota support. Moreover, available public opinion data for the vast majority of countries in the region facilitate a systematic assessment of the determinants of support for quotas. Thus, although our theory in general can be tested in other contexts, existing data allow us to focus on Latin America. The study of citizen support for gender quotas in the Latin American context is, however, a particularly pressing issue. Close to half of the countries in the region have already adopted gender quotas, and adoption of these continues to spread. In order to enhance the legitimacy of democratic regimes, it is imperative to identify the factors that promote citizen support for political institutions designed to improve gender equality in Latin America.

Our findings carry with them important policy implications. First and foremost, our results make it clear that unless governments demonstrate capacity to govern effectively, a variety of affirmative action policies, such as gender quotas, are unlikely to receive widespread public support. And we know from previous research that citizen support is critical for policy enactment and maintenance as well as future reforms (Brooks and Manza 2007; Soroka and Wlezien 2010). Thus, even though international actors and domestic elites have played an important role in quota adoption, there is every reason to believe that citizen support for gender quota policies can be instrumental not only for the adoption and continuation of quotas but also for the improvement of quota design. Numerous examples suggest that this has been the case in the Latin American context.

The "popular mobilization" of ordinary women to demand the adoption of quotas was an important factor in ushering change in many countries across Latin America and other regions of the world (Baldez 2004, 237). For example, in Argentina, on November 6, 1991, women's movements orchestrated a "massive mobilization" (Carrio 2005, 166) of over 5,000 women, who filled the parliamentary galleries and hallways and overflowed onto the streets to pressure political elites to adopt the quota law (Chama 2001). Beyond quota adoption, women's movements also motivated ordinary women to agitate for reforms to strengthen existing quota laws in Latin American countries such as Mexico, the Dominican Republic, and Ecuador (Araújo and García 2006). Many of these efforts were met with success, suggesting that ordinary citizens have influenced the process of quota adoption and reform in the region. Citizen support for quotas can then be particularly important for pressing political elites to expedite the strengthening of the quota laws recently enacted in El Salvador (municipal quotas) and Chile in 2015, which will certainly require additional reforms to be effective over time (Piscopo 2015). Taken together, our theory and findings indicate that good governance quality is critical for cultivating citizen support for gender quotas, which can ultimately result in the adoption and improvement of quota laws to guarantee high and continued women's numeric representation in parliament.

Our research also has important theoretical and policy implications beyond gender quota laws. As we elaborate in the conclusion, the theoretical framework we develop here can guide future research to identify the role of governance quality on citizen support for policies designed to improve the political representation of other disadvantaged and minority groups in society, such as ethnic and religious mi- 
norities. More broadly, our aim is to inform future research evaluating how governance quality influences citizen support for a variety of policies designed to strengthen democracy, including electoral and other institutional reforms. Improvements in governance quality may well also prove necessary for fostering citizen support for many of the policies currently topping the agendas of policy makers around the world.

\section{EXPLAINING CITIZEN SUPPORT FOR GENDER EQUALITY POLICIES: PREVIOUS STUDIES}

Prior research shows various individual traits and attitudes influence citizen support for gender equality policies. Sex, for example, is an important predictor of citizen support for policies that benefit women (Cassese and Hannagan 2014; Deckman and McTeague 2015). Due to self-interest, citizens are expected to favor policies that are likely to benefit them (e.g., Meltzer and Richard 1981; Sears and Funk 1990). Accordingly, existing work on support for gender quotas among citizens in Canada (Gidengil 1996) and political elites in Belgium (Meier 2008) finds that women are more likely to favor quotas than men. Previous research also shows that women are more likely than men to favor gender equality (Morgan and Buice 2013), and hence they also are more likely to support gender equality policies such as fair pay, parental leave, and protection from job discrimination in hiring and promotion (Cassese et al. 2015; Strolovitch 1998).

Although these findings give strong support to the selfinterest thesis, empirical literature also demonstrates that selfinterest is not enough to explain variation in citizen support for public policies in general and gender equality policies in particular. Pro-social values are also important determinants of support for public policies (Funk 2000). Belief in equality of opportunity (egalitarianism), for instance, predicts citizens' preferences for welfare policies (Bobo 1991; Feldman 1988). In the case of gender issues, individuals who hold gender egalitarian values report higher support for gender equality policies. Cassese et al. (2015), for example, find that in the United States, citizens who exhibit sexist attitudes are less likely to support policies to ensure equal pay for equal work.

We argue that explanations that focus on self-interest and pro-social values are still insufficient to explain support for quotas. As we theorize in the next section, at the individual level, political values (i.e., preferences for government involvement) should also play an important role in shaping citizen quota support. Yet individual-level accounts of citizen support for quotas still fall short. We maintain that explanations that do not consider the effect of contextual factors are incomplete. Accordingly, we develop an integrative theoretical model that takes into account the role of both individual and contextual factors.

\section{HOW DO CITIZENS FORM OPINIONS ON PUBLIC POLICY? AN INTEGRATIVE THEORETICAL MODEL}

We develop two sets of related hypotheses on how personal political values and contextual factors reinforce each other and together explain support for public policies. Although our theory is broad and can be applied to the study of public opinion on an array of public policies, our substantive focus is on citizen support for gender quota policies. At the individual level, we expect that, on average, favoring government involvement for improving citizens' well-being will increase gender quota support. In addition, we posit that the strength of this individual-level relationship will vary across countries. Contextual factors related to institutional performance will condition the impact of citizens' preferences for government involvement on quota support across countries and will also influence the overall-level of support for such quotas. Moreover, we draw hypotheses on how these dynamics differentially shape men's and women's quota support. Below we develop the theoretical basis for each of these claims and derive our specific hypotheses.

\section{The impact of political values}

Citizens' core political values are also important determinants of support for public policy. In particular, independent of ideological orientations (as measured by traditional liberalconservative or left-right scales), citizens' normative beliefs about the role government should play in improving living conditions shape policy preferences (Kumlin 2007), ${ }^{1}$ with those supporting government activism being more inclined to attribute responsibility to government for reducing inequality and protecting marginalized groups (Goren 2013). Accordingly, individuals who demand government intervention are more supportive of race-based affirmative action policies (Bobo and Kluegel 1993). Building on this research, we posit that gender-based affirmative action, in our case gender quotas, will on average enjoy higher support among those who favor an active role of government in improving ordinary citizens' lives. Consequently, we test the following hypothesis:

H1. On average, citizens who express higher support for government involvement to improve citizens' wellbeing will be more likely to support state-mandated gender quota policies.

However, we also argue that support for government involvement is more likely to translate into high support for

1. Ideology is only weakly correlated with citizens' beliefs about the role of government (Goren 2013; Zechmeister and Corral 2012), suggesting that these constructs are theoretically distinct. 
affirmative action policies for some citizens than for others. Citizens have different beliefs about the origins of social inequality, which in turn affect their support for policies designed to benefit marginalized groups, including gender equality policies (Burns and Gallagher 2010). Regarding gender issues, some citizens attribute gender inequality to discrimination and fewer opportunities in society, whereas others blame women's personal choices (Gurin 1985). Those who believe gender inequality is a product of structural barriers are more likely to support government intervention to mitigate gender disparities (Krook, Lovenduski, and Squires 2009). Consequently, we argue that individuals who simultaneously attribute gender disparities to unequal opportunities and also believe it is the government's responsibility to improve citizens' lives are more likely to support laws that give women a chance to be included in the candidate lists of political parties, that is, gender quotas. By contrast, people who believe that gender inequality is due to individual women's choices are likely to reject government intervention intended to increase opportunities for women (Gidengil 1996; Krook et al. 2009) regardless of their overall level of support for government involvement.

We posit that these dynamics have important consequences for determining how support for government involvement differentially affects men's and women's quota support. Even if both men and women favor government involvement, because men are far less likely than women to attribute gender disparities to unfair treatment and limited opportunities (Swim et al. 1995), men are subsequently much less likely than women to translate their general views on government involvement into support for gender quotas. For example, previous studies clearly demonstrate that women are more likely than men to believe that wage gaps occur due to differential treatment in the workplace and society (Cassese et al. 2015). Consequently, women are much more likely than men to consider government involvement essential for reducing wage gaps. Because men, by contrast, are more likely to believe that wage gaps are the product of individual women's choices, they tend to conclude that ensuring equal pay for women is "not the government's business" (Cassese et al. 2015, 13). Similarly, because women are more likely than men to attribute the underrepresentation of women in political posts to discrimination (Gidengil 1996), their support for government involvement on social issues will also hold the government responsible for leveling the playing field for women. Taking into account these insights, we derive the following hypothesis:

H2. Citizens who express higher support for government involvement will be more likely to support state-mandated gender quota policies, and this effect will be stronger for women than for men.

\section{Governance quality as heuristic information}

Even after considering their political values and predispositions, citizens may still lack the information needed to firmly determine their stand on a given policy. As a result, they are likely to seek external sources of information. In the absence of complete information, citizens resort to cues or messages they retrieve through "top of the head" processes with the objective of making inferences about a policy issue and subsequently determine their position on the policy (Zaller 1992). "Source cues" in particular-references to prominent political actors or institutions-serve as important heuristic information that can ease individuals' decisions on how much support to concede to a policy when they lack full information (Mondak 1992, 1993). Political institutions involved in the execution of a given policy can then condition citizens' policy endorsement. More specifically, literature in political psychology suggests that an institution's credibility aids citizens to evaluate the significance of policies associated with the institution and thus influences their level of policy support (Bartels and Mutz 2009). As Mondak (1992, 458) explains, institutional credibility functions as "a political currency" that allows political institutions to "purchase some increment of policy approval." These insights have important implications for the building of a theoretical model of citizen support for state-mandated gender quotas and other policies.

The first implication we draw from this literature is that the credibility of government, as given by the extent of governance quality in a country, is likely to provide important heuristic information employed by citizens to decide their level of support for public policy, including support for gender quota implementation. Through a top-of-the-head process, citizens are likely to search for objective evidence in their national context about their government's institutional credibility in being able to successfully execute its policy intentions. More specifically, our theory is distinct as it posits that, when determining their level of policy support, citizens rely on retrospective performance evaluations of the entire government apparatus they derive from their national context and that those evaluations are not limited to the incumbent's administration but go farther in time.

In contrast to literature on policy support that focuses on the effect of a lone political institution's credibility, such as the reputation of political parties (Downs 1957; Fiorina 1981), the Supreme Court (Mondak 1992), or Congress (Bartels and Mutz 2009), we maintain that citizens assess the worth of a given policy by processing heuristic infor- 
mation from their national context on the institutional capacity of government as a whole and thus on the capacity of the different institutions that make up government to work cooperatively and consistently produce good policy outcomes. Indeed, cross-national empirical evidence shows that the overall quality of policy is highly dependent on the capacity of different entities of government not only to efficiently carry out their individual mission but also to coordinate their efforts and work towards a common goal (Stein and Tommasi 2007). Consistent with this view, individuallevel studies for the United States demonstrate that confidence in government rooted in perceptions of government performance increases citizen support for public policy that benefits racial minorities (Hetherington 2005; Hetherington and Globetti 2002). Here we theorize that citizens resort to heuristic information on governance quality they obtain from their national context to inform their decision on their level of policy support. Consequently, our theory identifies the national context as an important source of heuristic information.

The second part of our argument states that the extent of a government's credibility is likely to hinge on its demonstrated capacity to consistently deliver good policy outcomes across policy areas. For instance, even if the incumbent administration competently implements a given policy, if the government has a track record of consistently failing to deliver across a range of policy domains that affect ordinary citizens' day-to-day lives (such as failure to provide basic services or fight crime and corruption), the government is unlikely to gain sufficient credibility in the eyes of the public to secure high policy support. Thus, independent of the incumbent administration's performance, the credibility of government is largely determined by its overall governance trajectory. Hence, we posit that a track record of poor governance lowers citizens' support for public policy. Conversely, a track record of good governance will instill confidence in government and increase support for public policy, including gender quotas. Taking into account these propositions, we hypothesize:

H3. In countries with a better track record of governance quality, citizens will be, on average, more likely to support state-mandated gender quota policies.

Although citizens are likely to rely on heuristic information derived from governance quality (i.e., source cues) to determine their level of policy support, recent research suggests that they will also take into account the content of the policy being described (Bullock 2011). Consequently, expressed policy preferences are not simply derived from readily accessible information in citizens' minds, such as the credibility of government, but also from their assessments of the policy in question. We extend this argument and posit that the degree to which citizens rely on heuristic information relative to policy content largely depends on citizens' personal interest in the policy being described. Self-interest motivations will be weighted more heavily in women's considerations to support gender equality policies than heuristic information provided by source cues, even if women had no prior knowledge of or experience with the policy. This implies that women will have a higher level of quota support than men, independent of whether a country has adopted a quota.

In contrast, in the absence of strong self-interest motivations, men will rely more heavily on source cues than on policy content to form their opinions on gender equality policies. Indeed, previous cross-national research shows that, when men form their opinions on gender issues, they are more amenable to elite cues derived from national context than women (Morgan and Buice 2013; Morgan, Espinal, and Hartlyn 2008). Consequently, we argue that the credibility of government will have greater influence on men's level of support for gender quotas than women's. Previous studies suggest that this is plausible. Hetherington and Globetti's (2002) findings for the United States, for example, indicate that at the individual level, confidence in government has a stronger effect on policy support among individuals who do not benefit directly from the policy. More specifically, we posit that heuristic information derived from national context on a government's track record of performance will particularly aid men to determine their extent of support for quota policies, independent of their initial level of information about quotas and whether or not their country has already adopted gender quotas laws. Therefore, we hypothesize that:

H4. In countries with a better track record of governance quality, citizens will be more likely to support state-mandated gender quotas, and this effect will be stronger for men than women, thereby reducing the gender gap in quota support.

\section{Bringing individual and contextual factors together}

The theoretical ideas presented above suggest that both personal political values and contextual factors related to governance quality will independently influence support for quotas and that each of these elements will have a differential effect on men's and women's levels of quota support. Political values and governance quality, however, are unlikely to work independently from each other. Our expecta- 
tion is that governance quality will moderate the individuallevel relationship between preferences for government involvement and support for quotas. This is because even if an individual holds normative beliefs that attribute responsibility to government in improving citizens' well-being, the same individual might not be highly supportive of the actual implementation of public policies that seek to achieve this goal if governance quality is poor. Therefore, a track record of poor government performance will attenuate the positive relationship between support for government involvement and support for quotas. In contrast, a track record of good governance quality will reinforce the positive impact of preferences for government involvement on quota support, as citizens will have more faith that this policy will actually lead to positive outcomes for society in general and women in particular. Consequently, hypothesis 5 is as follows:

H5. The positive relationship between support for government involvement and support for statemandated gender quota policies will be stronger in countries with a better track record of governance quality than in countries with a poor track record of governance quality.

We are then left with an integrative theoretical model that predicts interactive effects between three central variables: support for government involvement, governance quality, and sex. Support for quotas should peak among individuals who live in countries with relatively good governance and who also strongly support government involvement. Moreover, our theory indicates that, at the individual level, personal political values exert a stronger effect on women's attitude formation than on men's, increasing the gender gap particularly among citizens who strongly support government involvement. Nonetheless, in countries with good governance, the overall gender gap will be offset due to the stronger effect of governance quality on support for quotas among men than women. Thus, in countries with good governance, we should observe a smaller overall gender gap in support for quotas than in countries with poor governance. The end result is an overall higher level of support for quotas and a smaller gender gap in countries with good governance quality in comparison to those with poor governance. Thus, our final hypothesis states:

H6. Countries with a better track record of governance quality will show an overall higher level of citizen support for state-mandated gender quota policies, particularly among citizens with high sup- port for government involvement, and a smaller overall gender gap.

\section{DEPENDENT VARIABLE}

To evaluate the extent of citizen support for quotas, we employ a survey question included in the 2012 round of the Latin American Public Opinion Project (LAPOP) survey in 24 countries. On a scale from 1 (strongly disagree) to 7 (strongly agree), respondents were asked their extent of agreement with the following statement: "The state should require political parties to reserve some space on their lists of candidates for women, even if they have to exclude some men."

The wording of this survey item is particularly well suited for the Latin American case, because the vast majority of gender quotas that have been adopted across the region are state-mandated legislative gender quotas in which the state requires political parties to place female candidates on their party ballot. Another advantageous feature of the wording of this item is that it provides a description of the policy rather than referring to "gender quotas" per se. Consequently, even if a respondent is not familiar with the expression "gender quotas," he or she can still formulate an opinion on the policy described. Indeed, in countries with no quotas, when asked about their level of support for quotas using this survey item, only $2.6 \%$ of interviewees responded "do not know" and only $0.83 \%$ refused to provide an answer. The corresponding percentages in countries with quotas are virtually identical, $2 \%$ and $0.8 \%$ respectively.

Based on data for this survey item across the 24 countries in our sample, the average level of support for gender quotas is about 5 points. Yet there is also wide variation in support levels across countries, ranging from 3.73 in Trinidad and Tobago to 5.95 in El Salvador (fig. 1). A one-way ANOVA test revealed that differences in support for gender quotas across the 24 countries are statistically significant $(p<.001)$, suggesting that, once individual-level factors are taken into account, country-level characteristics may explain some of this variation. ${ }^{2}$ As depicted by the frequency distributions of the gender quota item across countries in

2. Based on the one-way ANOVA decomposition, we find that the proportion of the total variance that is accounted for by the variance between countries (i.e., the Intraclass Correlation Coefficient, ICC) is statistically significant $(p<.001)$ and equal to about $7 \%$. As explained in previous studies (e.g., Anderson and Singer 2008), in cross-national research, the variation between countries depicted by the ICC tends to be relatively small in studies that use survey data because the number of cases at the individual level is much larger than the number of cases at the country level. Our results clearly show that our core independent variable at the country level, Governance Quality, has a large and statistically significant effect on quota support. 


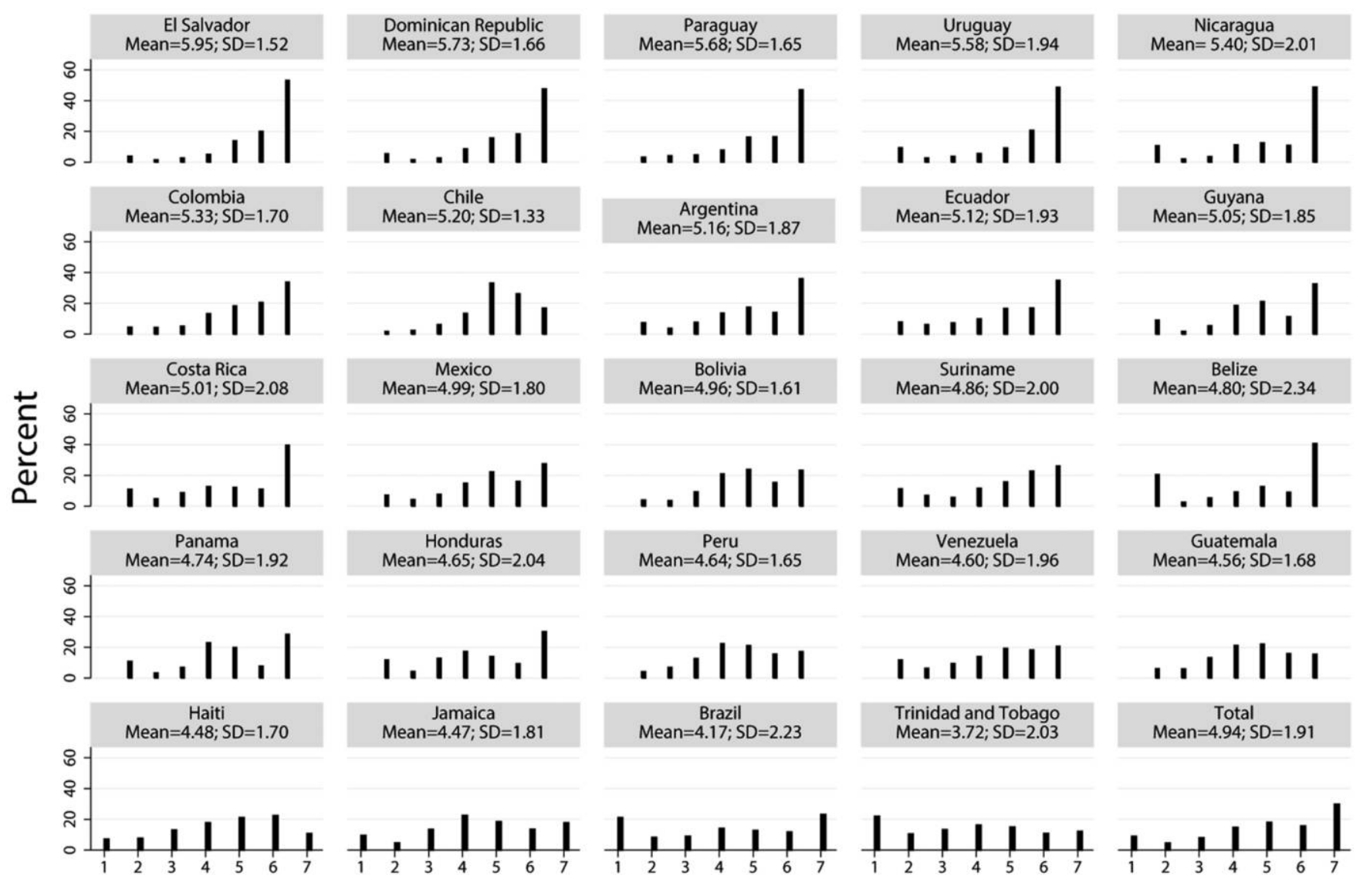

Figure 1. Frequency distribution: Support for gender quota by country; SD = standard deviation

figure 1 , there is also substantial within-country variation in quota support. In El Salvador, for example, quota support is highly skewed, resulting in the lowest within-country variation in our sample (SD = 1.52). More than half $(53 \%)$ of Salvadorans express the highest level of support for gender quotas (7 points), and only a small fraction (4\%) expresses the lowest level of support (1 point). Belize, by contrast, is the case with the largest within-country variation ( $\mathrm{SD}=$ 2.34). Although $41 \%$ of respondents express the highest level of support for quotas in Belize, 20\% express the lowest level of support. Our theory seeks to explain the variation in quota support observed both between and within countries.

\section{INDIVIDUAL- AND COUNTRY-LEVEL INDEPENDENT VARIABLES}

Our core independent variables at the individual level are sex and normative views about government involvement. ${ }^{3}$ Gender differences in quota support are assessed with the measure Sex, coded 1 for women and 0 for men. Support for

3. See the appendix for details on the coding, wording, and descriptive statistics of all variables in our analyses. Tables A1-C2 and figs. A1-C3 are located in the appendix. government involvement is measured with an index based on agreement with the following four survey items that capture citizens' views about government responsibility (vis-à-vis individuals or the private sector) for improving citizens' quality of life:

1. The government, more than individuals, should be primarily responsible for ensuring the well-being of the people.

2. The government, more than the private sector, should be primarily responsible for creating jobs.

3. The government should implement strong policies to reduce income inequality between the rich and the poor.

4. The government, more than the private sector, should be primarily responsible for providing health care services.

Responses for each of the items range from 1 (strongly disagree) to 7 (strongly agree). Factor analysis indicated that all four items load on a single factor and measure the same underlying construct-support for government involvement (see table A4 in the appendix, available online). 
The internal reliability of the index as measured by the Cronbach's alpha coefficient is 0.81 . The index was scaled to range from 1 to 7 , with 7 indicating the highest level of support.

At the country level, our core independent variable is a measure of Governance Quality. We use the Government Capabilities Index from the Political Institutions, Government Capabilities, and Public Policy International Dataset by the Inter-American Development Bank (Chuaire and Scartascini 2014). This index is particularly suitable for our study, because it captures overall governance quality across several policy areas and a government's general capacity to consistently deliver good policy outcomes, which we posit will serve as salient heuristic information for citizens to evaluate a government's credibility. Instead of focusing on a single policy area, the Government Capabilities Index measures a government's overall policy-making capacity. Moreover, the index takes into account the combined performance of four institutions found to be particularly important for predicting a government's policy-making capacitythe legislature, political parties, the judiciary, and the bureaucratic apparatus (Stein and Tommasi 2007). ${ }^{4}$ Finally, the measure incorporates the combined performance of these political institutions over more than a decade, instead of solely focusing on the performance of the incumbent administration. Values on the index range from 0 to 4, with lower values indicating lower levels of governance quality. Measured in this way, governance capacity in our sample ranges from a low of .342 for Haiti to a high of 2.39 for Chile and Jamaica. ${ }^{5}$

In addition to our main independent variables, we control for a number of country- and individual-level variables. Our argument suggests that a government's overall governance quality will influence citizens' support for quota policies, independent of gender quota implementation. Consequently, at the country level, we include in our models a Gender Quota Index, which takes into account whether a country had implemented a state-mandated gender quota before the LAPOP survey was fielded, and if it did, whether a placement mandate

4. For a description of the Government Capabilities Index, see appendix B. Importantly, to avoid a tautological relationship between the index and support for quotas, the index excludes policies related to the adoption of quotas, the gender composition of the legislature, or the type of electoral system in place (i.e., that may affect the likelihood of women being elected to office).

5. As a further robustness test, we replicate our analysis with an alternative measure of governance quality that relies on a different measurement strategy: the World Bank's Government Effectiveness Index. As we report in the appendix (table 7A and figs. A1-A4), our results remain substantively unchanged if we use the Government Effectiveness Index. A description of the Government Effectiveness Index is provided in appendix B. and enforcement mechanisms had also been implemented. Indeed, to ensure an effective quota policy, electoral engineers often promulgate rules that require parties to place female candidates in electable positions on their candidate lists (Baldez 2004; Krook 2009), and they also dictate enforcement mechanisms that require all parties competing in elections to comply with the quota rules (Jones 2009; Schwindt-Bayer 2009). ${ }^{6}$ Finally, we test the robustness of our results to the inclusion of variables that account for Years since Quota implementation and the Percent of Women in Parliament (see online appendix table A8), to test the possibility that the effect of governance quality on support for quotas is confounded by the longevity of quota laws or women's numeric representation in parliament.

To control for spurious sources of the relationship between good governance and support for quotas, we also control for other country-level factors, such as the Gross National Income (GNI) per capita using the most recent estimates available prior to the LAPOP survey. We also test the robustness of our results by including a measure of the level of democracy (Democracy Level) at the country level. Based on data from Freedom House International for 2011, "partly free" countries in our sample are coded 1 and "free" countries are coded zero. Finally, because the correlation between the Governance Quality, GNI, and Democracy Level variables is relatively high (ranging from 0.52 to 0.64 ), we show that our results are robust whether we include or exclude the democracy variable (see table 1) and whether we use an alternative measure of democracy, Polity IV (see appendix table A9).

At the individual level, since we hypothesize that the impact of support for government involvement will be independent of Ideology and Gender Egalitarian Attitudes, measures of both variables are included as controls. Ideology is measured by asking respondents to place themselves on a 10-point left-right scale. To simplify the analysis, this variable is collapsed into three categories denoting nominal ideology_Left, Center, and Right. Given that nonresponse rates are high for ideology, we also recode noresponse values as a category and include it in the analysis. To measure gender egalitarian attitudes, we employ a survey item that asks respondents their extent of agreement with the following statement: "Some say that when there is not enough work, men should have a greater right to jobs than women." We also test the robustness of our results to the inclusion of two alternative measures of gender egalitarian attitudes (see online appendix tables A11 and A12).

6. For more details about the construction of this variable, see table A2. 
To ensure that our results are independent of evaluations of the current government's performance, we control for a variable measuring Perceptions of Incumbent Government's Performance, which is an index based on four questions in the LAPOP survey asking citizens to rate the performance of the current administration on different policy domains, including its capacity to improve the economy and fight corruption. ${ }^{7}$ As the inclusion of women in politics is likely to be favored primarily among those who value democratic principles, we include a measure of Citizen Support for Democracy using a survey item that asks citizens to what extent they agree that "Democracy is better than other forms of government." Finally, we control for socioeconomic status and individual characteristics known to impact support for social policies including age, education, household wealth, ${ }^{8}$ employment status, rural residency, marital status, and number of children.

\section{METHOD}

To examine the country- and individual-level determinants of support for gender quotas, we estimate multilevel models that allow us to account for the nested nature our data, that is, individuals $i$ within countries $j$ (Snijders and Bosker 2012). A key characteristic of multilevel models is that coefficients can be allowed to vary randomly between groups (in our case countries). In their most basic form, multilevel models assume random effects for the coefficient associated with the intercept, and each group is allowed to have its own intercept. This feature is convenient, because, in contrast to classical regression analysis, it allows the estimation of standard errors taking into account the correlation of error terms within groups, producing more accurate results. In addition to a random intercept specification, researchers can also allow the coefficients associated with other variables in the model to vary randomly between groups. Yet, as Snijders and Bosker $(2012,106)$ explain, if there is theoretical reason to believe that an interaction between an individual-level variable and a group-level variable exists, as we do in this paper, this interactive effect can be tested using cross-level interaction terms, regardless of whether the individual-level variable has a random slope or not. The reason for this is that statistical tests for cross-level interactions supersede tests for random slopes $(2012,106) .{ }^{9}$ Following this advice, we test the significance of a three-way,

\footnotetext{
7. See table A5 for details about this variable.

8. For details on the construction of this variable, see Córdova (2008).

9. Snijders and Bosker $(2012,106)$ write that if there is a significant cross-level interaction, "the test for this interaction has a higher power to detect this [interaction] than the test for the random slope."
}

cross-level interaction between Sex, Support for Government Involvement, and Governance Quality, assuming only random intercepts (not random slopes). Thus, if our integrative theory is supported, we expect to find a positive and significant coefficient associated with this three-way cross-level interaction term.

To evaluate hypothesis 1 and hypothesis 3, we first need to estimate a baseline model (without the specification of cross-level interaction terms). Specifically, we expect that, on average, individuals who support government involvement will exhibit higher levels of support for quotas (hypothesis 1). In addition, we expect governance quality to have an independent direct positive effect on quota support (hypothesis 3). As a second step, we compare the results of our baseline model with one that includes a three-way interaction between sex, support for government involvement, and governance quality. The three-way interaction model specification also includes all lower-order terms that allow us to test our interactive hypotheses (hypotheses 2 and 4-6) while we hold other factors constant. Given that our dependent variable is ordinal (7-point scale), we estimate the following ordered logistic multilevel models with random intercepts:

$$
\begin{aligned}
& \text { Baseline Model: } \\
& \text { Support Quota } i j=\beta_{0}+\alpha_{1} \operatorname{Sex}_{1 i j} \\
& \quad+\alpha_{2} \operatorname{Support~Government~Involvement~}_{2 i j} \\
& \quad+\beta_{1} \text { Governance Quality } \\
& \quad+\ldots \beta_{n} X_{n i j}+U_{0 j}+\varepsilon_{i j} .
\end{aligned}
$$

Three-Way Interaction Model:

Support Quota $i j=\beta_{0}+\alpha_{1} \operatorname{Sex}_{1 i j}$

$+\alpha_{2}$ Support Government Involvement ${ }_{2 i j}$

$+\beta_{1}$ Governance Quality ${ }_{1 j}$

$+\gamma_{1}$ (Governance Quality Gex $\left._{1 i j}\right)$

$+\gamma_{2}$ (Support Government Involvement ${ }_{2 i j} \times \operatorname{Sex}_{1 i j}$ )

$+\gamma_{3}$ (Support Government Involvement ${ }_{2 i j}$

$\times$ Governance Quality $_{1 j}$ )

$+\gamma_{4}$ (Governance Quality $_{1 j}$

$\times$ Support Government Involvement $_{2 i j}$

$\left.\times \operatorname{Sex}_{1 i j}\right)+\ldots \beta_{n} X_{n i j}$

$+U_{0 j}+\varepsilon_{i j}$.

Here $U_{0 j}$ represent random effects for the intercept across countries, and $\varepsilon_{i j}$ are errors at the individual level.

\section{FINDINGS}

Models 1 and 2 in table 1 present the baseline model. As expected, we find that support for government involvement and governance quality have an independent positive effect on citizen support for quotas $(p<.001)$, lending support for 


\begin{tabular}{|c|c|c|c|c|}
\hline & Model 1 & Model 2 & Model 3 & Model 4 \\
\hline Sex $($ female $=1 ;$ male $=0)$ & $\begin{array}{l}.362^{* * *} \\
(.028)\end{array}$ & $\begin{array}{l}.355^{\star * *} \\
(.028)\end{array}$ & $\begin{array}{l}1.068^{* *} \\
(.351)\end{array}$ & $\begin{array}{l}1.049^{* *} \\
(.365)\end{array}$ \\
\hline Support for Government Involvement & $\begin{array}{l}.366^{* * *} \\
(.013)\end{array}$ & $\begin{array}{l}.373^{\star * *} \\
(.012)\end{array}$ & $\begin{array}{l}.369^{* * *} \\
(.044)\end{array}$ & $\begin{array}{l}.382^{* * *} \\
(.047)\end{array}$ \\
\hline Governance Quality (Government Capabilities Index) & $\begin{array}{l}.317^{* * *} \\
(.035)\end{array}$ & $\begin{array}{l}.389^{* * *} \\
(.039)\end{array}$ & $\begin{array}{l}.537^{\star *} \\
(.171)\end{array}$ & $\begin{array}{l}.623^{* * *} \\
(.182)\end{array}$ \\
\hline Sex $\times$ Support for Government Involvement & & & $\begin{array}{r}-.082 \\
(.063)\end{array}$ & $\begin{array}{r}-.080 \\
(.065)\end{array}$ \\
\hline Sex $\times$ Governance Quality & & & $\begin{array}{l}-.779^{* *} \\
(.237)\end{array}$ & $\begin{array}{c}-.755^{* *} \\
(.248)\end{array}$ \\
\hline Governance Quality $\times$ Support for Government Involvement & & & $\begin{array}{r}-.022 \\
(.029)\end{array}$ & $\begin{array}{c}-.025 \\
(.031)\end{array}$ \\
\hline Sex $\times$ Governance Quality $\times$ Support for Government Involvement & & & $\begin{array}{c}.105^{\star} \\
(.042)\end{array}$ & $\begin{array}{c}.102^{\star} \\
(.044)\end{array}$ \\
\hline \multicolumn{5}{|l|}{ Country-level controls: } \\
\hline Quota Index & $\begin{array}{l}.185^{* * *} \\
(.012)\end{array}$ & $\begin{array}{l}.084^{* * *} \\
(.011)\end{array}$ & $\begin{array}{l}.075^{* * *} \\
(.012)\end{array}$ & $\begin{array}{l}.084^{* * *} \\
(.011)\end{array}$ \\
\hline GNI per Capita & $\begin{aligned}-1.757^{* * *} \\
(.184)\end{aligned}$ & $\begin{array}{l}-.718^{* * *} \\
(.184)\end{array}$ & $\begin{aligned}- & 1.722^{* * *} \\
& (.213)\end{aligned}$ & $\begin{array}{l}-.682^{* * *} \\
(.185)\end{array}$ \\
\hline Democracy level (partly free $=1$; free $=0$ ) & & $\begin{array}{l}.197^{\star * *} \\
(.037)\end{array}$ & & $\begin{array}{l}.203^{* * *} \\
(.037)\end{array}$ \\
\hline \multicolumn{5}{|l|}{ Individual-level controls: } \\
\hline Left (ideology $1-3=1 ; 8-10=0$ ) & $\begin{array}{l}.116^{*} \\
(.045)\end{array}$ & $\begin{array}{r}.103^{*} \\
(.045)\end{array}$ & $\begin{array}{r}.111^{*} \\
(.045)\end{array}$ & $\begin{array}{c}.104^{*} \\
(.045)\end{array}$ \\
\hline Center (ideology $4-5=1 ; 8-10=0$ ) & $\begin{array}{r}-.010 \\
(.041)\end{array}$ & $\begin{array}{r}-.016 \\
(.041)\end{array}$ & $\begin{array}{r}-.010 \\
(.041)\end{array}$ & $\begin{array}{c}-.012 \\
(.041)\end{array}$ \\
\hline Right (ideology $6-7=1 ; 8-10=0$ ) & $\begin{array}{c}-.041 \\
(.044)\end{array}$ & $\begin{array}{r}-.032 \\
(.044)\end{array}$ & $\begin{array}{r}-.035 \\
(.045)\end{array}$ & $\begin{array}{c}-.027 \\
(.044)\end{array}$ \\
\hline Ideology nonresponse $(=1 ; 8-10=0)$ & $\begin{array}{c}-.032 \\
(.046)\end{array}$ & $\begin{array}{c}-.033 \\
(.046)\end{array}$ & $\begin{array}{c}-.034 \\
(.046)\end{array}$ & $\begin{array}{c}-.027 \\
(.046)\end{array}$ \\
\hline Support for democracy & $\begin{array}{l}.094^{* * *} \\
(.009)\end{array}$ & $\begin{array}{l}.093^{\star * *} \\
(.009)\end{array}$ & $\begin{array}{l}.092^{\star * *} \\
(.009)\end{array}$ & $\begin{array}{l}.093^{\star * *} \\
(.009)\end{array}$ \\
\hline Gender egalitarian attitudes & $\begin{array}{l}.021^{* *} \\
(.007)\end{array}$ & $\begin{array}{l}.018^{\star *} \\
(.007)\end{array}$ & $\begin{array}{l}.021^{\star *} \\
(.007)\end{array}$ & $\begin{array}{l}.019^{* *} \\
(.007)\end{array}$ \\
\hline Perception of incumbent government's performance & $\begin{array}{l}.031^{\star *} \\
(.010)\end{array}$ & $\begin{array}{l}.035^{\star * *} \\
(.010)\end{array}$ & $\begin{array}{l}.032^{\star *} \\
(.010)\end{array}$ & $\begin{array}{l}.035^{\star * *} \\
(.010)\end{array}$ \\
\hline Quintiles of wealth & $\begin{array}{c}.017^{+} \\
(.010)\end{array}$ & $\begin{array}{l}.019^{+} \\
(.010)\end{array}$ & $\begin{array}{l}.019^{+} \\
(.010)\end{array}$ & $\begin{array}{c}.020^{+} \\
(.010)\end{array}$ \\
\hline Education level & $\begin{array}{c}.027 \\
(.022)\end{array}$ & $\begin{array}{l}.017 \\
(.022)\end{array}$ & $\begin{array}{c}.028 \\
(.022)\end{array}$ & $\begin{array}{l}.017 \\
(.022)\end{array}$ \\
\hline Rural $(=1 ;$ urban $=0)$ & $\begin{array}{r}-.057^{+} \\
(.031)\end{array}$ & $\begin{array}{c}-.053^{+} \\
(.031)\end{array}$ & $\begin{array}{r}-.054^{+} \\
(.031)\end{array}$ & $\begin{array}{c}-.052^{+} \\
(.031)\end{array}$ \\
\hline Married or common law marriage $(=1$; single $=0)$ & $\begin{array}{c}-.016 \\
(.034)\end{array}$ & $\begin{array}{r}-.006 \\
(.034)\end{array}$ & $\begin{array}{r}-.008 \\
(.034)\end{array}$ & $\begin{array}{r}-.003 \\
(.034)\end{array}$ \\
\hline Divorced, separated, or widowed $(=1$; single $=0)$ & $\begin{array}{r}-.109^{*} \\
(.055)\end{array}$ & $\begin{array}{r}-.093^{+} \\
(.055)\end{array}$ & $\begin{array}{r}-.099^{+} \\
(.055)\end{array}$ & $\begin{array}{r}-.086 \\
(.055)\end{array}$ \\
\hline Number of children & $\begin{array}{l}.002 \\
(.008)\end{array}$ & $\begin{array}{l}.003 \\
(.008)\end{array}$ & $\begin{array}{c}.003 \\
(.008)\end{array}$ & $\begin{array}{c}.003 \\
(.008)\end{array}$ \\
\hline Age & $\begin{array}{l}.000 \\
(.001)\end{array}$ & $\begin{array}{r}-.000 \\
(.001)\end{array}$ & $\begin{array}{l}.000 \\
(.001)\end{array}$ & $\begin{array}{r}-.000 \\
(.001)\end{array}$ \\
\hline
\end{tabular}

Note. Number of respondents $=17,083$; number of countries $=24$. Multilevel ordered logit models with random intercepts. These results were produced using Stata 13.1 using the "meologit" command. Standard errors are in parentheses.

${ }^{+} p<.10$.

${ }^{*} p<.05$.

$* * p<.01$

${ }^{* * *} p<.001$ 
hypotheses 1 and 3. These findings are consistent with our theory that both political values and heuristic information derive from institutional credibility are important determinants of quota support. Moreover, self-interest, as measured by sex, also influences citizen support for gender quotas, with women expressing higher support than men. ${ }^{10}$

Models 3 and 4 in table 1 present the results associated with our interactive hypotheses (hypotheses 2 and 4-6). Given that testing these hypotheses requires taking into account a series of interactions between three variables (Sex, Support for Government Involvement, and Governance Quality), we evaluate each hypothesis based on the fully specified model that includes the three-way interaction and all lower-order constitutive terms. The positive and statistically significant coefficient associated with the three-way interaction term lends preliminary support for our integrative theory, indicating that the effect of each of the three variables on support for quotas is conditional on the others. As Kam and Franzese (2007) point out, however, the signs and statistical significance of interactions and their constituent terms can be difficult to interpret, especially in nonlinear models. Indeed, interaction and constitutive terms lack meaning on their own. We therefore follow the recommendation of Brambor, Clark, and Golder (2006) to present substantive effects and their confidence intervals graphically. We present the predicted probabilities generated from estimates of model 4 in table 1 . Specifically, we estimate mean predicted probabilities taking into account the information for each individual in our sample across all the independent variables included in our models. ${ }^{11}$

We display graphically the average predicted probability of having the highest level of support for quotas, namely, a level of 7 on the 1-7 scale. Panels $A$ and $B$ in figure 2 evaluate graphically hypotheses 1 and 2 , respectively. As hypothesis 1 predicts, we find that, other things being equal, there is a strong positive relationship between support for government involvement and support for gender quotas (panel $A$ in fig. 2). Yet, as hypothesis 2 suggests, this finding is more nuanced. Women are more likely to favor gender quotas than men when support for government involvement is high. As shown in panel $B$, at the lowest level of

10. We also find that citizens who have strong beliefs about democracy being the best form of government, who display gender egalitarian attitudes, who place themselves on the Left (i.e., 1-3) of the left-right Ideology scale, and who perceive that the incumbent administration is doing a good job show higher levels of support for quotas. SES and demographic factors, however, do not exert a strong effect.

11. Predicted probabilities were computed using the command "margins" in Stata 13.1. support for government involvement, men and women have a similar probability of supporting quotas-about $11 \%$. When support for government involvement is at its highest level (7 on a 7-point scale), however, a significant gender gap emerges: women are about 10 percentage points more likely than men to express high support for quotas, at $58.4 \%$ versus $48.0 \%$, respectively.

As shown by panels $A$ and $B$ of figure 3, hypotheses 3 and 4 are also supported by the data. Consistent with hypothesis 3 , we find that governance quality significantly increases support for quotas on average (panel $A$ ), but also, consistent with hypothesis 4 , the size of this effect varies between men and women (panel $B$ ). Panel $A$ demonstrates a strong substantive effect of governance quality, where the probability of strongly supporting quotas is $32.8 \%$ for countries with the lowest level of governance quality, but rises almost 20 percentage points to $51.1 \%$ for countries with the highest level.

Moreover, panel $B$ in figure 3 shows that for countries like Haiti at the lowest end of the Government Capabilities Index, the average probability of expressing high support for quotas is $27.9 \%$ and $38.8 \%$ among men and women, respectively, a difference of more than $10 \%$. Yet, at the highest level of the Government Capabilities Index, the gender gap effectively vanishes, with the probability of having high support for quotas at $49.4 \%$ for men and $54.0 \%$ for women. Consistent with hypothesis 4, this finding demonstrates that in countries with much lower governance quality, men have more reasons for opposing gender quotas than women. Not only are men less likely to perceive such programs as being in their self-interest but also the poor track record of their government in implementing policies effectively erodes support for quotas.

Next, we evaluate hypothesis 5, which posits that the effect of support for government involvement on quota support is stronger among individuals who live in countries with a better track record of governance quality than in countries with a poor track record. Figure 4 , panels $A$ and $B$, display the effect of support for government involvement on quota support among individuals who live in a country with poor governance quality (a score lower than one) and good governance quality (a score higher than two), respectively. ${ }^{12}$ The patterns observed in figure 4 provide strong support for hyothesis 5. Among citizens who live in countries with poor governance quality (panel $A$ ), the probability of having high

12. An alternative graphical representation of this result is presented in fig. A5. This figure is also reproduced for our alternative measure of governance quality (the Government Effectiveness Index) in fig. A6. 

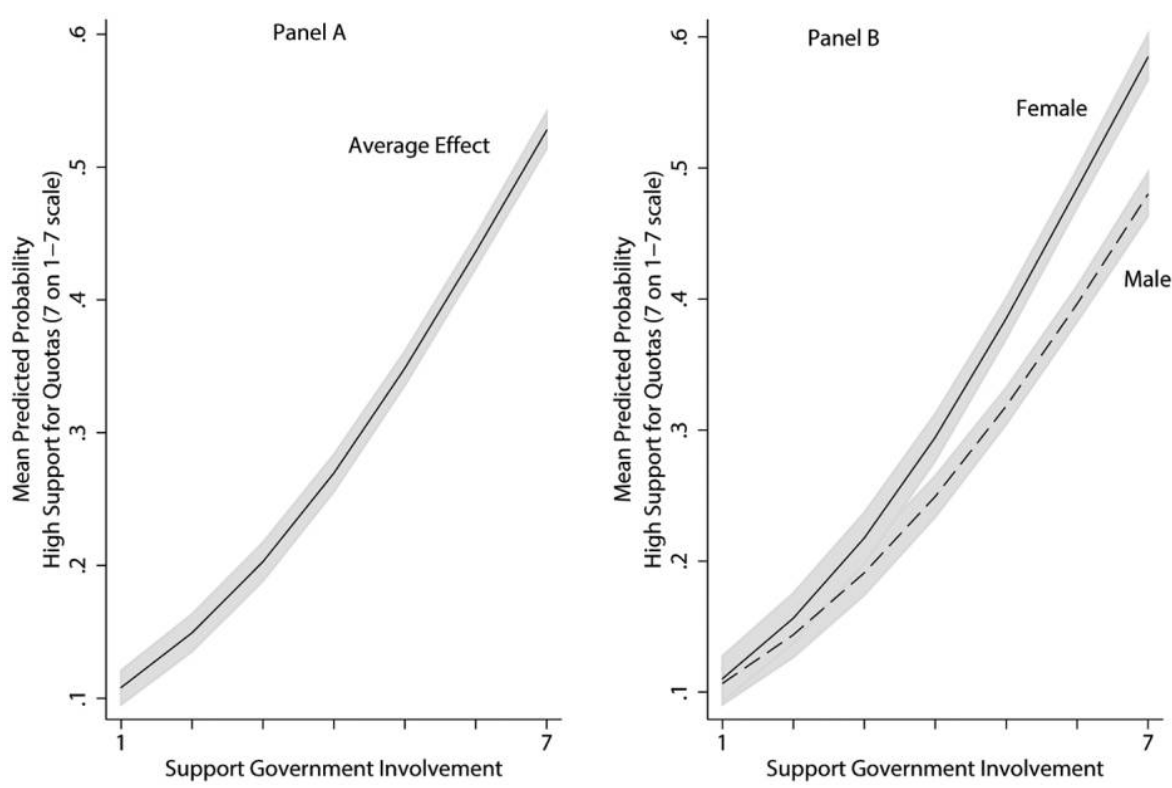

Figure 2. Effect of Preference for Government Involvement. Mean predicted probabilities were computed based on model 4 in table 1. Shaded areas represent $95 \% \mathrm{Cls}$ estimated using the delta method.

support for quotas increases from $10.4 \%$ to $49.3 \%$ as one moves from the lowest to the highest level of support for government involvement, resulting in an increase in quota support of $38.9 \%$. By comparison, among citizens who live in countries with good governance quality (panel $B$ ), mov-

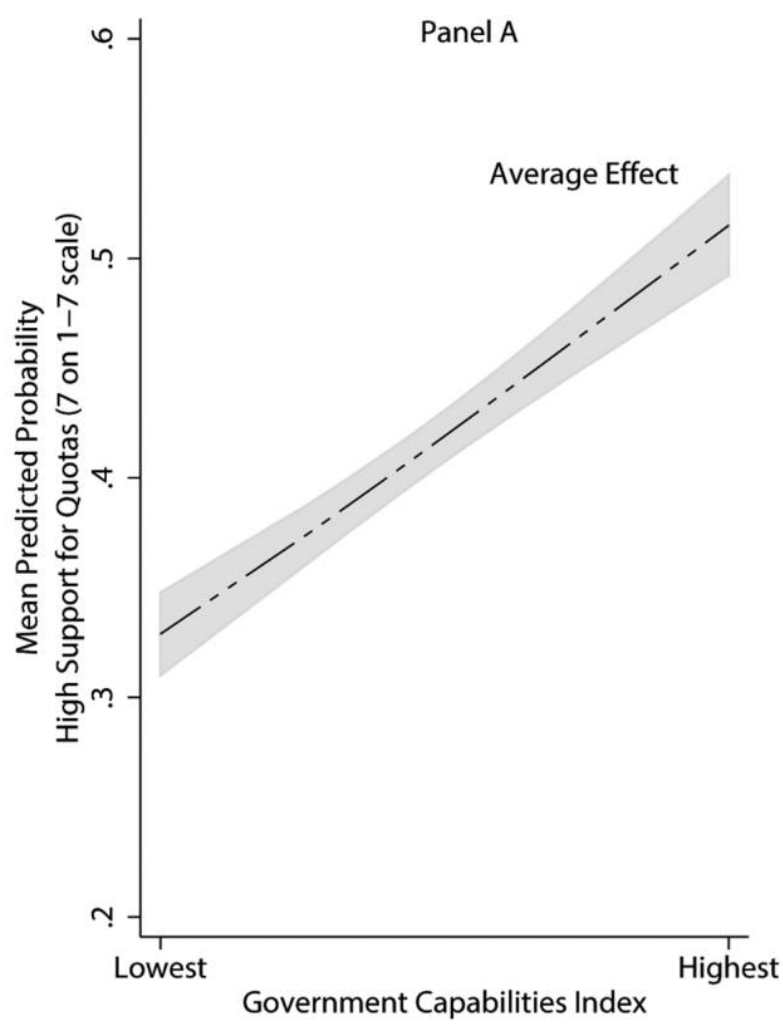

ing from the lowest to the highest levels of support for government involvement results in a significantly larger increase $(47.3 \%)$ in quota support.

In the last part of our analysis, we test the hypothesis that countries with a better track record of governance quality will

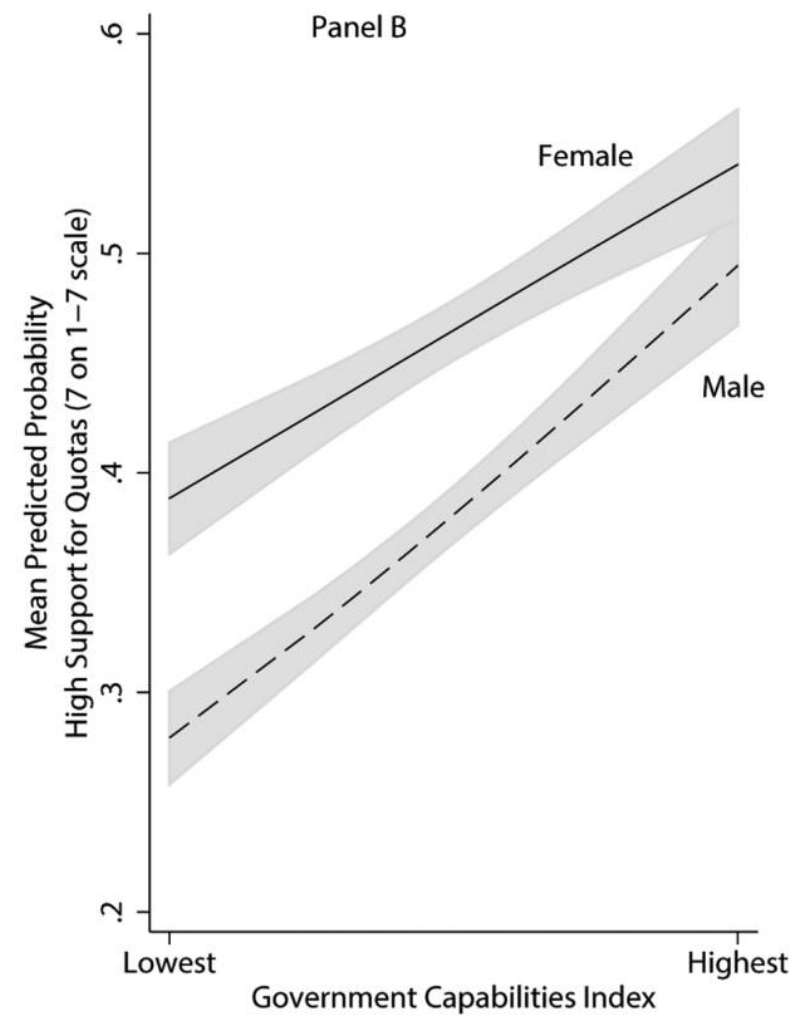

Figure 3. Effect of Governance Quality. Mean predicted probabilities were computed based on model 4 in table 1. Shaded areas represent $95 \%$ Cls estimated using the delta method. 

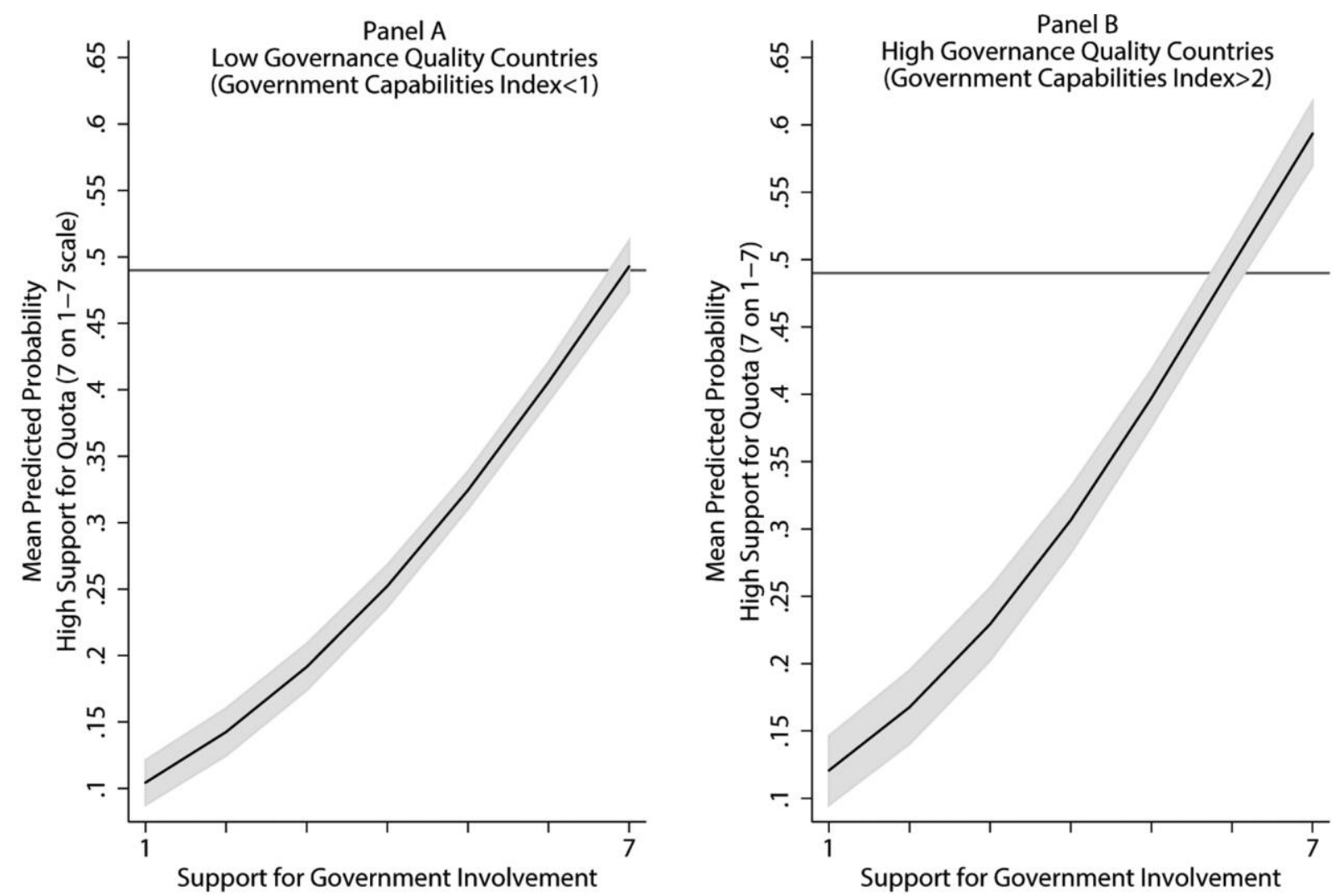

Figure 4. Effect of Governance Quality by Support for Government Involvement. Mean predicted probabilities were computed based on model 4 in table 1. Shaded areas represent $95 \% \mathrm{Cls}$ estimated using the delta method.

show an overall higher level of citizen support for statemandated gender quota policies - particularly among citizens with high support for government involvement-and a smaller overall gender gap (hypothesis 6). Figure 5 shows how the positive and significant three-way interaction in table 1 translates into support for hypothesis 6. Panel $A$ presents the effects of preferences for government involvement on quota support in countries in our sample with relatively low governance quality (i.e., with a score lower than 1 on the Government Capabilities Index), and panel $B$ graphs this relationship for countries with high governance quality (i.e., with a score higher than 2 on the index). As panel $B$ plainly shows, consistent with hypothesis 6 , the effects of governance quality on quota support depend on both support for government involvement and gender. Not only is the overall level of support for quotas higher but also the overall gender gap in support for quotas is smaller in countries with good governance quality (panel $B$ ) than in countries with poor governance (panel $A$ ). Specifically, the overall probability of having high support for quotas is $9.9 \%$ higher in countries with good governance quality than in countries with poor governance, and this effect is primarily driven by individuals who strongly support government involvement. Further- more, the overall gender gap in support for quotas is half the size in countries with good governance than in countries with poor governance-shrinking from $10.4 \%$ to $5.2 \%$. The gap diminishes in panel $B$ due to the much stronger effect of good governance quality on men's support for gender quotas than on women's support.

\section{FURTHER ROBUSTNESS CHECKS: TESTING ALTERNATIVE MECHANISMS}

The positive and statistically significant coefficient associated with Quota Index in table 1 indicates that citizens in countries with an effective quota law express stronger support for quotas. This suggests that in addition to governance quality, individuals living in countries with effective quota laws may also use heuristic information derived from quota laws to form opinions about state-mandated gender quotas. Indeed, research suggests that whether people form a positive or negative opinion regarding a given policy also depends on how well the policy is designed and implemented (Campbell 2012). According to this perspective, policy implementation carries "informational content" that serves as a cue to citizens when deciding their support for that policy (Pierson 1993, 619). Actual experience with 

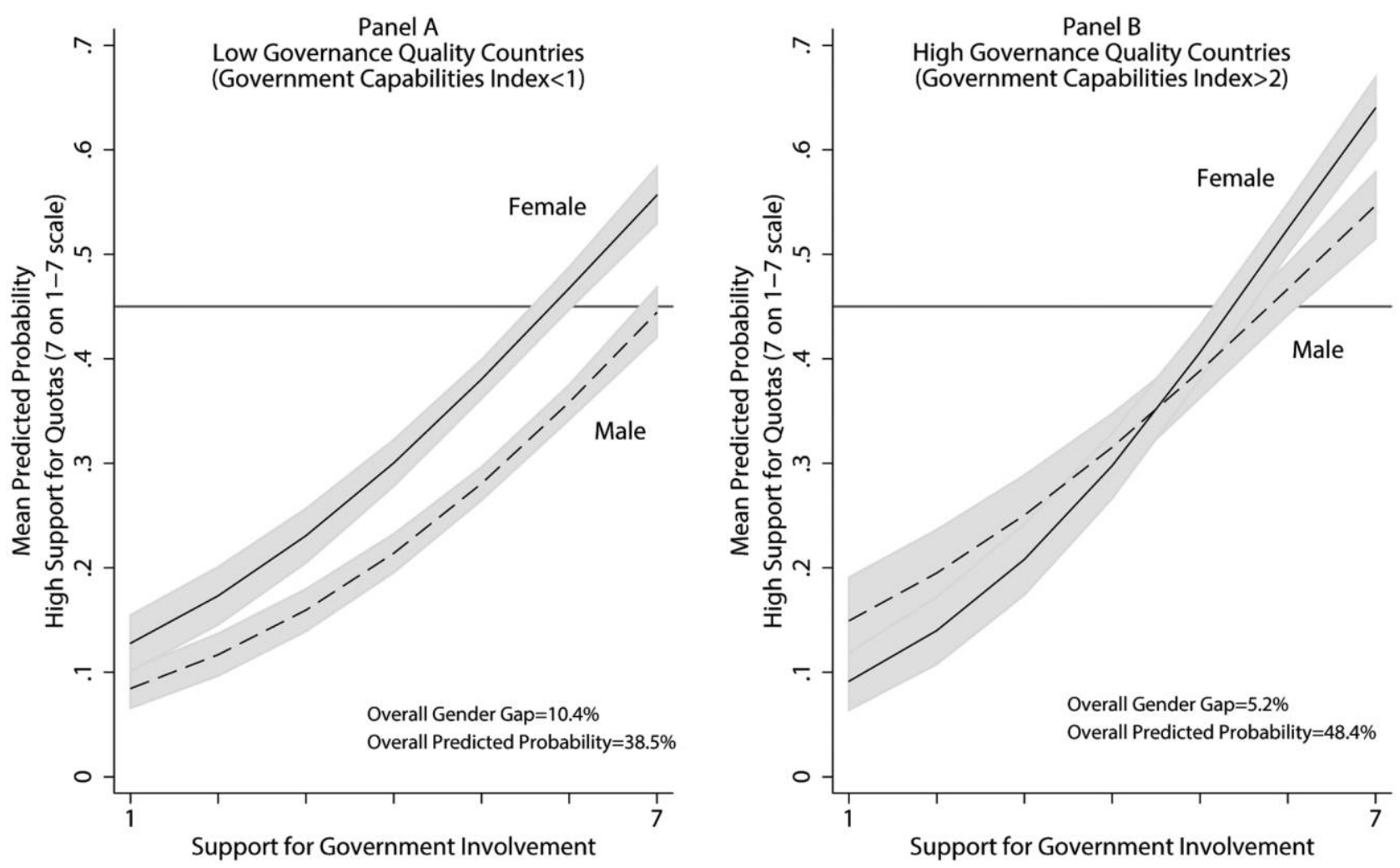

Figure 5. Effect of Governance Quality by Sex and Preference for Government Involvement. Mean predicted probabilities were computed based on model 4 in table 1. Shaded areas represent $95 \% \mathrm{Cls}$ estimated using the delta method.

quota implementation may then affect quota support in ways similar to the ones we hypothesize governance quality will impact quota support. Effective quota laws might nurture public support for quotas, particularly among individuals who strongly support government involvement, and also reduce the gender gap. To evaluate the predictive power of our theory on governance quality relative to the plausible effect of quota implementation, we add a three-way interaction between Quota Index, Support for Government Involvement, and Sex to the model specification in table 1 . See model 1 in table $\mathrm{C} 1$ in the online appendix.

The results from this model specification show that all of the coefficients associated with the terms used to test hypotheses 1-6 are comparable to those in table 1. The coefficients are in the same direction, have remarkably similar magnitudes, and show the same levels of statistical significance, indicating that the results presented in table 1 are robust to this new model specification. Additionally, the coefficient associated with the three-way interaction between Quota Index, Support for Government Involvement, and Sex is not statistically significant $(p=.217$; see model 1 of online table C1). ${ }^{13}$

13. Given that this three-way interaction is not statistically significant, we reestimate the model without this term. Once again we find that the
The effectiveness of quota laws in a given country can, however, also impact support for quotas through two other mechanisms. For one, it may be that the effect of governance quality on quota support is reinforced by the implementation of effective quotas. Alternatively, it may be that citizens in countries without quotas are more likely to use heuristic information derived from governance quality, whereas in countries with quotas citizens rely more on information derived from quota design. We tested these two possibilities by adding an interaction between Governance Quality and Quota Index to model 1 in table 1 (see appendix table $\mathrm{C} 2$ ).

The results presented in table 1 are also robust to this model specification. Again, we find that the signs, magnitudes, and statistical significance of the coefficients that test our integrative theory remain virtually unchanged when

results support all our hypotheses (hypotheses 1-6). The results of this new model estimation also show a negative and significant relationship between Quota Index and Sex and a positive and significant relationship between Quota Index and Support for Government Involvement (model 2 of table $\mathrm{C} 1$ ). To further investigate these findings, we graph and explain these results in figs. $\mathrm{C} 1$ and $\mathrm{C} 2$ in the appendix. The effects associated with the quota index are much smaller than the conditional effects of general governance effectiveness and, as noted, do not compromise in any way the robust effects described thus far. 
we add this interaction term. We do, however, find a negative and significant interaction term between Governance Quality and Quota Index $(p<.05)$, indicating that the effectiveness of quota laws do moderate the relationship between governance quality and support for quotas. To evaluate the direction and magnitude of this effect, we graph the predicted probability of strongly supporting quotas across the entire range of the Government Capabilities Index for countries without a quota (Quota Index $=0$ ) and countries with the most effective quotas (Quota Index $=3$ ). See appendix, figure C3.

We observe that a better track record of governance quality is associated with a higher overall level of support for quotas in countries with and without quotas but that the effect of governance quality is slightly stronger in countries without quotas. As one moves from countries with the lowest to the highest governance quality, the increase in quota support is only 4 percentage points higher in countries without quotas than in countries with the most effective quotas. This weak moderating effect does not change our overall conclusion regarding the importance of governance quality. The relationship between good governance and support for quotas is strong and positive, regardless of the implementation or design of gender quotas. In short, individuals are not relying on governance quality as a heuristic only in the absence of quotas.

\section{CONCLUSIONS}

Our theoretical framework and findings provide a new lens for examining the determinants of citizen support for gender quotas, in particular, as well as support for other affirmative action policies and state-led initiatives aimed at improving democracy more generally. Specifically, our theory and findings on support for gender quotas can guide future research to identify how governance quality impacts citizen support for other policies. Our study provides a systematic analysis of how governance quality, individual traits, and political values shape citizen support for gender quotas across 24 countries, making it the most comprehensive study of its kind. We conclude by briefly describing our main findings and discussing their policy implications as well as their relevance for the study of citizen support for other state-led initiatives.

The first finding to emerge from our research is that citizens' normative beliefs about the role of government in society are important determinants of support for quota policies, independent of other individual level factors such as self-interest, gender egalitarian attitudes, and ideology. Individuals who strongly support government action in the improvement of citizens' well-being are more likely to support gender quotas. Moreover, consistent with our expectations, high support for government involvement results in stronger quota support among women than menmost likely because women are more prone than men to attribute gender disparities to unfair treatment rather than to women's decisions.

Further, citizens also rely on heuristic information they draw on from their national context to determine their level of quota support. A government's track record of governance quality serves as a cue to citizens trying to decide their level of quota support, and men are more inclined to resort to this contextual information than women. Consequently, government credibility exerts a stronger positive impact on men's support for quotas than women's. In addition, the effect of good governance is strongest among citizens who favor government involvement. In the end, our results indicate that, compared to countries with poor governance, countries with a track record of good governance quality display higher levels of citizen support for quotas-particularly among those who strongly support government involvement-and a smaller overall gender gap in quota support.

The stronger effect of governance quality on quota support among men than women suggests that good governance may also narrow the gender gap in citizen support for other gender equality policies, such as fair pay and equal access to employment. Beyond gender issues, governance quality can play a role in shaping support for other affirmative action policies currently topping the agendas of political elites and international organizations, such as state-mandated quotas (or reserved seats) for ethnic and religious minorities in political decision-making bodies. Latin American countries such as Bolivia, Colombia, Peru, and Venezuela have all adopted ethnic quotas. Quotas for minorities have also been adopted in other socially and ethnically diverse countries across the globe (Bjarnegård and Zetterberg 2014; Krook and O'Brien 2010). Consequently, although political values such as support for government involvement may help explain attitude formation for policies intended to improve the lives of marginalized citizens, support for affirmative action policies in general is likely to be highest in countries with good governance.

In addition to engendering support for affirmative action policies, government capacity has the potential to also impact attitude formation toward other state-led initiatives, such as institutional or electoral reforms, that are salient in Latin America and other newly established democracies. In recent years, several Latin American countries have undergone a number of institutional reforms, including government decentralization and electoral reforms such as new 
ballot designs and state-mandated primary elections. Our research suggests that if states demonstrate weak capacity to govern, it is unlikely that institutional and electoral reforms will be highly supported by the citizenry.

We conclude by highlighting the policy implications of our results. Our findings suggest that investments in strengthening state capacity can nurture political legitimacy by increasing citizen support for gender quota policies. Ultimately, high support for quotas can serve to pressure political elites to adopt, maintain, and strengthen gender quota laws and thus guarantee their continued success. Hence, our findings stress the importance of organizations devoted to improving governance quality across the globe. Well-performing governments are fundamental for achieving citizen support for public policies to reduce gender inequalities, and thus for promoting representative democracies. Good governance can aid in the building of stronger democracies by enhancing citizen support for policies that provide women with more opportunities to be part of their country's economic, social, and political life.

\section{ACKNOWLEDGMENTS}

We would like to thank Emily Beaulieu, Jesse Johnson, Mark Peffley, Justin Wedeking, participants of the 2015 research workshop in the Department of Political Science at University of Kentucky, the editor, and three anonymous reviewers for very useful comments. We thank Dakota Thomas for excellent research assistance. Further, we thank the Latin American Public Opinion Project (LAPOP) and its major supporters (the United States Agency for International Development, the Inter-American Development Bank, and Vanderbilt University) for making the survey data available. The two authors are equal contributors to this research.

\section{REFERENCES}

Alexander, Amy C. 2012. "Change in Women's Descriptive Representation and the Belief in Women's Ability to Govern: A Virtuous Cycle." Politics and Gender 8 (4): 437-64.

Anderson, Christopher J., and Matthew M. Singer. 2008. "The Sensitive Left and the Impervious Right: Multilevel Models and the Politics of Inequality, Ideology, and Legitimacy in Europe." Comparative Political Studies 41 (4/5): 564-99.

Araújo, Clara, and Ana Isabela García. 2006. “The Experience and the Impact of Quotas in Latin America.” In Druda Dahlerup, ed., Women, Quotas, and Politics. New York: Routledge.

Baldez, Lisa. 2004. "Elected Bodies: The Gender Quota Law for Legislative Candidates in Mexico." Legislative Studies Quarterly 29 (2): 231-58.

Barnes, Tiffany D. 2016. Gendering Legislative Behavior. New York: Cambridge University Press.

Barnes, Tiffany D., and Stephanie M. Burchard. 2013. “'Engendering’ Politics: The Impact of Descriptive Representation on Women's Political
Engagement in Sub-Saharan Africa." Comparative Political Studies 47 (7): 767-90.

Bartels, Brandon L., and Diana C. Mutz. 2009. "Explaining Processes of Institutional Opinion Leadership.” Journal of Politics 71 (1): 249-61.

Bauer, Gretchen, and Manon Tremblay. 2011. Women in Executive Power: A Global Overview. New York: Routledge.

Bjarnegård, Elin, and Pär Zetterberg. 2014. "Why Are Representational Guarantees Adopted for Women and Minorities? Comparing Constituency Formation and Electoral Quota Design within Countries." Representation 50 (3): 307-20.

Bobo, Lawrence. 1991. "Social Responsibility, Individualism, and Redistributive Policies." Sociological Forum 6 (1): 71-92.

Bobo, Lawrence, and James R. Kluegel. 1993. "Opposition to Race-Targeting: Self-Interest, Stratification Ideology, or Racial Attitudes?” American Sociological Review 58 (4): 443-64.

Brambor, Thomas, William Roberts Clark, and Matt Golder. 2006. "Understanding Interaction Models: Improving Empirical Analyses.” $\underline{P_{0}-}$ litical Analysis 14 (1): 63-82.

Brooks, Clem, and Jeff Manza. 2007. Why Welfare States Persist: Public Opinion and the Future of Social Provision. Chicago: Chicago University Press.

Bullock, John G. 2011. "Elite Influence on Public Opinion in an Informed Electorate." American Political Science Review 105 (3): 496-515.

Burns, Nancy, and Katherine Gallagher. 2010. "Public Opinion on Gender Issues: The Politics of Equity and Roles.” Annual Review of Political Science 13:425-43.

Bush, Sarah Sunn. 2011. "International Politics and the Spread of Quotas for Women in Legislatures.” International Organization 65 (1): 103 37.

Campbell, Andrea. 2012. "Policy Makes Mass Politics." Annual Review of Political Science 15 (1): 333-51.

Carrió, Elisa María. 2005. “Argentina: A New Look at the Challenges of Women's Participation in the Legislature." Women in Parliament: Beyond Numbers. Stockholm: IDEA.

Cassese, Erin, Tiffany D. Barnes, and Regina Branton. 2015. "Racializing Gender: Public Opinion at the Intersection." Politics and Gender 11 (1): $1-15$.

Cassese, Erin, and Rebecca Hannagan. 2014. “Framing and Women's Support for Government Spending on Breast Cancer Research and Treatment Programs." Analyses of Social Issues and Public Policy 15 (1): 69-88.

Chama, Mónica. 2001. Las Mujeres y el Poder. Buenos Aires: Ciudad Argentina.

Chuaire, Maria Franco, and Carlos Scartascini. 2014. "Political Institutions, State Capabilities, and Public Policy: An International Dataset, 2013 Update.” Inter-American Development Bank, Washington, DC.

Clayton, Amanda. 2015. "Women's Political Engagement under QuotaMandated Female Representation: Evidence from a Randomized Policy Experiment." Comparative Political Studies 48 (3): 333-69.

Córdova, Abby. 2008. "Methodological Note: Measuring Relative Wealth Using Household Asset Indicators.” AmericasBarometer Insights 6:1-9.

Córdova, Abby, and Gabriela Rangel. Forthcoming. "Addressing the Gender Gap: The Effect of Compulsory Voting on Women's Electoral Engagement." Comparative Political Studies.

Dahl, Robert Alan. 2006. On Political Equality. New Haven, CT: Yale University Press.

Deckman, Melissa, and John McTague. 2015. "Did the War on Women Work? Women, Men, and the Birth Control Mandate in the 2012 Presidential Election.” American Politics Research 43 (1): 3-26

Downs, Anthony. 1957. An Economic Theory of Democracy. New York: Harper. 
Escobar-Lemmon, Maria, and Michelle Taylor-Robinson. 2005. "Women Ministries in Latin American Governments: When, Where and Why." American Journal of Political Science 49 (2): 829-44.

Feldman, Stanley. 1988. "Structure and Consistency in Public Opinion: The Role of Core Beliefs and Values." American Journal of Political Science 32 (2): 416-40.

Fiorina, Morris P. 1981. Retrospective Voting in American National Elections. New Haven, CT: Yale University Press.

Franceschet, Susan, and Jennifer Piscopo. 2008. "Gender Quotas and Women's Substantive Representation: Lessons from Argentina.” Politics and Gender 4 (3): 393-425.

Funk, Carolyn L. 2000. “The Dual Influence of Self-interest and Societal Interest in Public Opinion.” Political Research Quarterly 53 (1): 37-62.

Gidengil, Elisabeth. 1996 "Gender and Attitudes toward Quotas for Women Candidates in Canada." Women and Politics 16 (4): 21-44.

Goren, Paul. 2013. On Voter Competence. New York: Oxford University Press.

Gurin, Patricia. 1985. “Women's Gender Consciousness.” Public Opinion Quarterly 49 (2): 143-63.

Hetherington, Marc J. 2005. Why Trust Matters: Declining Political Trust and the Demise of American Liberalism. Princeton, NJ: Princeton University Press.

Hetherington, Marc J., and Suzanne Globetti. 2002. "Political Trust and Racial Policy Preferences.” American Journal of Political Science 46 (2): 253-75.

Htun, Mala N., and Mark P. Jones. 2002. "Engendering the Right to Participate in Decision-Making: Electoral Quotas and Women's Leadership in Latin America." In Nikki Craske and Maxine Molyneux, eds., Gender and the Politics of Rights and Democracy in Latin America. New York: Palgrave.

Hughes, Melanie M., Mona Lena Krook, and Pamela Paxton. 2015. "Transnational Women's Activism and the Global Diffusion of Gender Quotas." International Studies Quarterly 59 (2): 357-72.

IDEA (International Institute for Democracy and Electoral Assistance). 2015. Quota Project: Global Database of Quotas for Women.

Jones, Mark P. 2009. "Gender Quotas, Electoral Laws, and the Election of Women: Evidence from the Latin American Vanguard." Comparative Political Studies 42 (1): 56-81.

Kam, Cindy D., and Robert J. Franzese Junior. 2007. Modeling and Interpreting Interactive Hypotheses in Regression Analysis. Ann Arbor: University of Michigan Press.

Krook, Mona Lena. 2009. Quotas for Women in Politics: Gender and Candidate Selection Reform Worldwide. New York: Oxford University Press.

Krook, Mona Lena, Joni Lovenduski, and Judith Squires. 2009. "Gender Quotas and Models of Political Citizenship." British Journal of Political Science 39 (4): 781-803.

Krook, Mona Lena, and Diana Z. O’Brien. 2010. “The Politics of Group Representation: Quotas for Women and Minorities Worldwide." Comparative Politics 42 (3): 253-72.

Kumlin, Steffan. 2007. “The Welfare State: Values, Policy Preferences, and Performance Evaluations." In Russell J. Dalton and Hans-Dieter Klingemann, eds., Oxford Handbook of Political Behavior. New York: Oxford University Press.

Lipset, Seymour Martin. 1983. Political Man: The Social Bases of Politics. London: Heinemann.

Meier, Petra. 2008. "A Gender Gap Not Closed by Quotas: The Renegotiation of the Public Sphere." International Feminist Journal of Politics 10 (3): 329-47.
Meltzer, Allan H., and Scott F. Richard. 1981. "A Rational Theory of the Size of Government." Lournal of Political Economy 89 (5): 91427.

Mondak, Jeffery J. 1992. "Institutional Legitimacy, Policy Legitimacy, and the Supreme Court." American Politics Quarterly 20 (4): 457-77.

Mondak, Jeffery J. 1993. "Public Opinion and Heuristic Processing of Source Cues.” Political Behavior 15 (2): 167-92.

Morgan, Jana, and Melissa Buice. 2013. "Latin American Attitudes toward Women in Politics: The Influence of Elite Cues, Female Advancement, and Individual Characteristics.” American Political Science Review 107 (4): 644-62.

Morgan, Jana, Rosario Espinal, and Jonathan Hartlyn. 2008. "Gender Politics in the Dominican Republic: Advances for Women, Ambivalence from Men." Politics and Gender 4 (1): 35-63.

O’Brien, Diana Z. 2015. "Rising to the Top: Gender and Party Leadership in Advanced Industrial Democracies." American Journal of Political Science 59 (4): 1022-39.

O’Brien, Diana Z., and Johanna Rickne. 2016. "Gender Quotas and Women's Access to Leadership Post.” American Political Science Review 110 (1): 112-26.

Pierson, Paul. 1993. "When Effect Becomes Cause: Policy Feedback and Political Change." World Politics 45 (4): 595-618.

Piscopo, Jennifer M. 2015. "States as Gender Equality Activists: The Evolution of Quota Laws in Latin America." Latin American Politics and Society 57 (3): 27-49.

Schwindt-Bayer, Leslie A. 2009. "Making Quotas Work: The Effect of Gender Quota Laws on the Election of Women." Legislative Studies Quarterly 34 (1): 5-28.

Sears, David O., and Carolyn L. Funk. 1990. "Self-Interest in Americans' Political Opinions.” In Jane J. Mansbridge, ed., Beyond Self-Interest. Chicago: University of Chicago Press.

Snijders, Tom A. B., and Roel Bosker. 2012. Multilevel Analysis: An Introduction to Basic and Advanced Multilevel Modeling. Los Angeles: Sage.

Soroka, Stuart N., and Christopher Wlezien. 2010. Degrees of Democracy: Politics, Public Opinion, and Policy. New York: Cambridge University Press.

Strolovitch, Dara Z. 1998. "Playing Favorites: Public Attitudes toward Race and Gender Targeted Anti-discrimination Policy." National Women's Studies Association Journal 10 (3): 27-53.

Stein, Ernesto, and Mariano Tommasi. 2007. "The Institutional Determinants of State Capabilities in Latin America." In François Bourguignon and Boris Pleskovic, eds., Annual World Bank Conference on Development Economics Regional: Beyond Transition. Washington, DC: World Bank.

Swim, Janet K., Kathryn J. Aikin, Wayne S. Hall, and Barbara A. Hunter. 1995 "Sexism and Racism: Old-Fashioned and Modern Prejudices." Lournal of Personality and Social Psychology 68 (2): 199-214.

Tripp, Aili Mari, and Alice Kang. 2008. "The Global Impact of Quotas: On the Fast Track to Female Representation." Comparative Political Studies 41 (5): 338-61.

Zaller, John R. 1992. The Nature and Origins of Mass Opinion. New York: Cambridge University Press.

Zechmeister, Elizabeth J., and Margarita Corral. 2012. "Individual and Contextual Constraints on Ideological Labels in Latin America." Comparative Political Studies 46 (6): 675-701.

Zetterberg, Pär. 2009. "Do Gender Quotas Foster Women's Political Engagement? Lessons from Latin America." Political Research Quarterly 62 (4): 715-30 